with a mouse," he said. If anyone believed the Commission should go through that kind of agony again, he was mistaken, said the Commissioner. The Commission should scuttle programmes far sooner when member states do not agree.

Not that Davignon is against Community support for biotechnology far from it. Rather, he appears to detest the national bickering which delayed the programme so long. His policy now is to set up a "framework for research", a broad structure of ministerial agreement on Brussels research and development policy. The framework would stretch over, say, five years, leaving the Commission room to develop detailed programmes within the

\section{Fusion decision awaited}

\section{Brussels}

The next EEC research council on $8 \mathrm{March}$ is now likely to approve the next five-year programme on controlled thermonuclear fusion. The fear that there might be a gap in the sliding programmes, between the last budgetary allocation and this, was further reduced with the release last week of a favourable opinion from the Consultative Committee for the Fusion Programme, which considers the planned financial envelope $-1,500$ million European Currency Units ( $£ 750$ million) has been allowed.

Continued membership by Sweden, one of the two non-EEC countries participating, is, however, in jeopardy. The committee observes that Sweden finds the cost excessive. One difficulty is that neither Sweden nor Switzerland participates in the EEC's annual budgetary procedure, when the amount of money devoted to a programme can be adjusted. National contributions are assessed on the basis of a percentage of gross national product, and for Sweden more money for the EEC programme means less for national research.

The Commission's thermonuclear research strategy, which is to concentrate effort on the tokamak line while retaining an interest in magnetic confinement, reverse field pinch and stellerators, wins the approval of the committee, which nevertheless recommends a periodic assessment of the relevance of these side-lines to reactor development.

The committee is, however, more cautious in its views on the step to be taken after JET, the Joint European Torus now nearing completion at Culham in Britain. It recommends that plans for the next large thermonuclear machine, called NET (for Next European Torus), should be reviewed again before a decision is made in 1984. Likewise the committee is noncommittal on the need for the proposed tritium laboratory. guidelines and giving nation states the chance to see a fair return on Community investment in a much wider context.

This framework is to be thrashed out in the next two meetings of the Council of Ministers for research, one in March and the next in June. If nothing happens in 1982, the momentum will be lost, says Davignon. But the transition from the present structure to the new one will be gradual. Some heads have already rolled at the Directorate-General for Research, but Davignon's cabinet insists that the night of the long knives will not last long. The objective is to use existing staff in new ways, Davignon claims - although some Commission staff remain nervous.

And to what end? To revitalize European industry. Davignon, whose commission also covers energy and industry affairs, says Brussels research and development has a way of redirecting European economic development, to fill gaps - such as in telematics and computers - in relation to the Japanese and United States competition. To achieve this, Davignon is prepared to be surprisingly flexible, and sees a role for the Commission even in helping to set up bilateral research and development projects among member states, and in giving international promotion to national centres of excellence. Davignon hopes member states will agree to his ambitious programme because of the economic risks involved in not doing so.

Robert Walgate

\section{US university funding}

\section{Tax act fails}

\section{Washington}

Universities in the United States are complaining that so far they have benefited little from the Reagan Administration's attempts to augment spending on research by tax cuts rather than direct support.

On the one hand, the tax cuts were structured in such a way that it has been equally, if not more, tempting to a company to increase its internal research efforts rather than contract work to outside groups. On the other, there is a feeling that the new incentives will have little effect on some of the largest companies which already have relatively low tax liabilities.

Two parts of the Economic Tax Recovery Act signed by President Reagan last summer were supposed to help universities, one a tax credit designed to increase industry support for basic research at universities, the other a new deduction for industries contributing research equipment to universities.

"Neither appears to hold significant promise," Dr John C. Crowley of the Association of American Universities (AAU), which follows legislative affairs for the major US research universities, told a recent meeting of the American Association for the Advancement of Science.
Dr Crowley quoted a letter from Mr B.J. McKelvain, an analyst with General Electric Company, which has been among the most aggressive companies seeking tax incentives to boost spending on research and development. Mr McKelvain presents the company's estimate that the research tax credit will result in an increase of less than two per cent in industry-funded research.

The difference in the incentive for increased support of university research compared with in-house work is probably "negligible", Mr McKelvain had written. And although he says that the incentive for equipment donations should result in some increased giving, "we would not expect the response to have a significant impact on the critical shortage of state-of-the-art equipment available for university research".

The principal reason for this pessimistic assessment is based on the narrow scope of the tax provisions. For example, any equipment donated by a company must have been manufactured by that company and cannot contain purchased parts accounting for more than 50 per cent of the tax costs.

"Despite these limitations, the equipment donation provision is a start in the right direction. If broadened somewhat, it could have a considerable impact on the problem", said Dr Crowley, one of the coauthors of a report prepared by AAU for the National Science Foundation two years ago. This formed the basis for the Carter Administration's proposal to provide an additional $\$ 7$ million in the foundation's budget for university research equipment, but was one of the first items to be cut by the Reagan Administration when it came to power last January.

As for the broader impact of the new tax laws, Dr Crowley concludes that the 1981 Tax Act offers "only token incentives for research support and donations of research equipment by industry".

This view is confirmed by officials from several major universities. $\mathrm{Mr}$ Stuart H. Cowen, for example, vicepresident for financial arrangements at the Massachusetts Institute of Technology, said that, so far, the institute had "not seen much effect of the new tax law", although speculating that companies may be holding back until the Treasury Department publishes detailed guidelines on how the law will be interpreted.

Although disappointed, few university officials are surprised at the apparent failure of the bill. Whereas they had pushed hard for inclusion in the tax legislation of a clause allowing companies to write off all contributions to university basic research against tax, the Treasury Department was not convinced that the value of this move would outweigh the costs in terms of lost revenue; the bill as finally passed by Congress merely allows for tax relief on the amount that support for such research is increased by a company.

Several congressmen are hoping to 
introduce legislation that would reinstate the original objective.

The universities are also worried about a new bill passing through Congress which could require that up to three per cent of the federal government expenditure on research and development should go to small businesses.

David Dickson

\section{Telecommunications}

\section{Gear on sale at last}

Users of the British telephone network can now legally buy handsets from retail shops. This is the first tangible effect of the Telecommunications Act, passed last November to liberalize part of British Telecom's business. Users may, however, be disappointed that the choice of telephones on the market has not yet increased. So far, only four types of handset have been certified for sale through general retail outlets, all of which British Telecom also markets itself. Twenty-five further requests for certification are waiting in the wings.

The aim of the act is to encourage open competition between manufacturers of equipment for connection to the public network. British Telecom will still retain control of the network but will have the right to connect only the first instrument. The liberalization is to be phased over three years, starting with handsets and discrete modems (digital analog interfaces, as they are known in the trade), followed by integral modems this spring, equipment not using call switching or loudspeakers in July, simple telex-teleprinters in October and, finally, private automatic branch exchanges (PABXs) in July 1983.

The British Standards Institution (BSI) has been charged with the task of drawing up compatibility standards for each type of equipment. Certification of individual items will be taken over by a newly-created subsidiary of the British Electrotechnical Approval Board (BEAB) later in the year.

So far, the liberalization seems to be going according to plan. But users and manufacturers have been concerned that it may be too slow. The system cannot get into full swing until BSI, which must follow lengthy procedures under its charter, has drawn up standards and BEAB has set up the machinery required for certification. Moves by BSI, however, to reorganize existing staff and appoint more and to reduce the time taken for public comment on draft standards to one month seem to have quelled some fears. First drafts for seven standards including plugs, handsets, modems, teleprinters and appliances to be connected to private circuits leased from British Telecom, are due to be published within a few months. Earlier wrangles over the terms under which BEAB would operate also seem to have been resolved. It is now hoped that an independent subsidiary will go into business in July.

Meanwhile, manufacturers have little alternative than to accept the role of British Telecom, one of their competitors, as the approval agency and that of the Department of Industry in selecting applications for consideration. These interim arrangements, however, do not seem to have been a deterrent. The department has already received applications for many types of equipment, the latest being for PABXs from Ferranti, GTE, Harris Systems, Mitel Telecommunications, ITT Business Systems, Philips Business Systems, and Plessey Office Systems. One company, International Business Machines, is planning to be use the liberalization to introduce equipment new to the British market. It is installing an Integrated Networking System, which allows separate telephone switchboards to operate as one, at the American Express International Banking Corporation.

On terminal equipment at least, there seems to be continued optimism that the liberalization will work without destroying too many manufacturers' hopes.

Judy Redfearn

\section{Soviet biotechnology Keeping a secret}

Last month's annual general meeting of the Soviet Academy of Sciences placed a special stress on the development of Soviet biotechnology. Academician Ovchinnikov stressed especially the achievements of biotechnology. Soviet scientists, he said, were now leading the world in " a number of very important branches of biology".

Ovchinnikov's summing-up covers a major confrontation during the past year among scientists involved in biotechnology. There appears to have been a power struggle between Ovchinnikov and his supporters from the physical chemical wing and Academician Dubinin representing the biologists. After some manoeuvring, Ovchinnikov emerged victorious and Dubinin retired from active scientific life. At the same time, there was considerable criticism in the Soviet press of the management of molecular biology research which, since May 1974, has had "top priority" status.

Another and more interesting confrontation has apparently been going on between the academy's biologists and the military scientific sector. This began two years ago when Professor David Goldfarb, a Jewish biologist, applied to emigrate to Israel. Professor Goldfarb had previously been involved in work on bacterial plasmids, and therefore, according to the emigration authorities, his work could be classified as secret. Several Western scientists wrote to Academician Ovchinnikov on Professor Goldfarb's behalf, but received only noncommittal answers. According to the latest information, however, certain academicians have spoken out clearly to say that in their opinion Professor Goldfarb's work was not secret. This accords with the fact that Professor Goldfarb was never cleared by the security authorities for access to secret information. The whole matter appears to reflect not merely the usual blocking of a Jewish scientist wishing to emigrate but a genuine conflict between the academy and the security establishment over what is and is not secret information in the field of biotechnology.

Vera Rich

\section{Pasteur institute}

\section{Rien ne change pas}

\section{Paris}

Francois Gros, science adviser to the prime minister of France, has thrown in his lot with politics. He has resigned as director of the Institut Pasteur in Paris, one of the most famous of laboratories. The laboratory was founded in 1888 by Louis Pasteur, and since then it has been directed by a series of well-known biologists: Gros, a Nobel laureate himself, took over from Jacques Monod. The call of the new politics in France must be great!

The new incumbent - who took up his job this month - is Raymond Dedonder, 60 , previously director of the Institute of Molecular Biology of the University of Paris. Dedonder is a microbiologist with a strong inclination towards the application of his work to the economy and to medicine - something already well-established in the tradition of the Pasteur. He has worked with Bacillus subtilis, of interest to industrial genetic engineering; and with Bacillus thuringiensis, contributing to the development of a bacterial toxin against certain insects.

It is unlikely that Dedonder will much change directions at the Pasteur. He spent a large part of his early career there and so is a "Pasteur man" - and Gros himself is likely to continue to take a fatherly interest from the prime minister's office.

So plans made under Gros's directorship - and, in fact, under the previous government - will not change. A new laboratory of immunology has been established and a laboratory of biotechnology will be set up, to come into operation in 1984. The independent management of the Pasteur is likely to continue, despite the fact that half the institute's money comes from government. Dedonder believes that far from wanting to nationalize the Pasteur - as some have suggested - the government wishes to take it as a model of fruitful symbiosis between basic and applied research.

The one change that may come with the new directorship - and new government - is a greater emphasis on the overseas laboratories of the Pasteur, particularly those in Third World countries, such as the Instituts Pasteur in Tunis, Algier, Casablanca, Dakar and so on, in line with the government's foreign policy. Dedonder will be encouraging that development. 